\title{
SHEAR WAVE VELOCITIES OF PROMINENT GEOLOGIC FORMATIONS IN THE NELSON-TASMAN REGION
}

\author{
Rebecca Ryder ${ }^{1}$, Liam M. Wotherspoon ${ }^{2}$ and Andrew C. Stolte ${ }^{3}$
}

(Submitted January 2021; Reviewed June 2021; Accepted August 2021)

\begin{abstract}
This paper presents the development of representative shear wave velocity profiles for the prominent geologic formations in the Nelson-Tasman region of New Zealand. Shear wave velocity $\left(\mathrm{V}_{\mathrm{s}}\right)$ profiles to depths of up to $100 \mathrm{~m}$ were developed at over 50 sites using a combination of active source and passive source surface wave testing. Using this data and regional geologic information, $\mathrm{V}_{\mathrm{s}}$-depth models were developed for six of the prominent geologic formations. Comparison with existing $\mathrm{V}_{\mathrm{S}}$-depth models from New Zealand and international studies highlighted the significantly higher shear wave velocities of the deposits in this region. $V_{S}$ exceeded $750 \mathrm{~m} / \mathrm{s}$ for the Moutere Gravels and Port Hills Gravels at relatively shallow depths, representative of rock deposits. However, while the Port Hills Gravels transition to a conglomerate rock below depths of $30 \mathrm{~m}$ or less, the Moutere Gravel formation is an uncemented clay-bound gravel. The young gravel and sand deposits have $V_{s}$ higher than those from other regions. As the region is thought to have undergone cycles of geologic uplift, the resulting over-consolidation of these deposits could explain the high Vs. Horizontal-to-vertical spectral ratio testing was not able to characterise the fundamental site period across the region, likely due to the weak impedance contrast that would exist at the gravel-rock interface at depth. These outcomes highlight the importance of regional geotechnical and geophysical characterisation to constrain the salient features that can control potential seismic site amplification and site classification.
\end{abstract}

\section{INTRODUCTION}

In New Zealand, recent earthquakes have demonstrated the influence of near surface soil profile characteristics and sedimentary basin structures on site amplification, with these often referred to as site effects. These site effects are important on the local site scale for the design and assessment of structures; and on the regional scale to assess impacts on distributed infrastructure and understand the effects of 3D basin geometry on ground motions. Site effects have been the focus of a large body of research, with significant developments following the observed and recorded effects of the 1964 Niigata, 1964 Alaska, 1967 Caracas and 1971 San Fernando earthquakes [1-2]. The 1985 Michoacan Mexico [3] and 1989 Loma Prieta, USA [4] earthquakes were significant because of the increase in the density of strong motion instrumentation across a range of soil conditions. Ground motions during the Canterbury Earthquake Sequence (CES) were recorded by a dense network of strong motion stations (SMSs), with ground motion records across multiple events clearly demonstrating the variability in amplification as a result of site stratigraphy and wider basin effects [5-6]. The 2013 Cook Strait EQs [7] and 2016 Kaikōura earthquakes further demonstrated the influence of local site conditions and sedimentary basins on ground motions in Wellington [8]. Key to understanding these effects is characterisation of the shear wave velocity $\left(\mathrm{V}_{\mathrm{S}}\right)$ of different geologic deposits and their stratigraphic characteristics, both locally and across wider basin structures.

Prior to the CES there was very little knowledge of the dynamic site characteristics and shear wave velocity of regional geologic deposits across New Zealand, and the variability of these properties from one region to the next. Apart from a handful of detailed site characterisation studies in Wellington [9] and the Hutt Valley [10], few regions in New Zealand had been characterised to a level that would allow for direct quantification of $V_{s}$ profile and basin effects [11]. This paucity of data has motivated new geophysical investigations in recent years across New Zealand, particularly in areas affected by recent earthquakes.

Observations of the strong ground motion and amplification in the CES was the motivation of recent studies including Wood et al. [12] and Wotherspoon et al. [13], with a focus on the near surface $\mathrm{V}_{\mathrm{S}}$ profiles at strong ground motion stations (SMS) in Christchurch. Deeper characterisation of the urban Christchurch area was undertaken using surface wave testing methods by Teague et al. [14]. Wotherspoon et al [15] collated over 80 site period estimates across the Canterbury Plains, and deep V $V_{\text {s }}$ profiles at Canterbury Plains SMS were developed by Deschenes et al. [16]. Some of this information was combined with other geophysical and invasive test data to develop a 3D velocity model for the Canterbury region [17]. Following the 2016 Kaikōura earthquake deep Vs characterisation was carried out across the Wellington central business district using surface wave methods [18] and a large suite of site period estimates were collated $[19,20]$. This was combined with new subsurface investigation data to improve the constraints on the basin geometry and soil profile characteristics [20].

Away from areas that have been affected by recent earthquakes, studies have improved the understanding of regional deposits in an effort to inform future design and assessment. This includes Auckland [21], Tauranga [22] and Waikato [23], among others. National models for the time averaged $\mathrm{V}_{\mathrm{S}}$ over a depth of $30 \mathrm{~m}$ ( $\left.\mathrm{V}_{\mathrm{S} 30}\right)$ have been developed for New Zealand $[24,25]$ in an effort to provide some level of wider representation on the variability of near surface soil deposits across the country.

This paper presents the development of representative $V_{S}$ profiles for the major geologic formations in the NelsonTasman region. The motivation for this research was to collect region-specific data that could be used to inform dynamic site

\footnotetext{
1 University of Auckland, Auckland

2 Corresponding Author, Associate Professor, University of Auckland, Auckland, l.wotherspoon@auckland.ac.nz (Fellow)

3 University of Canterbury, Christchurch, andrew.stolte@canterbury.ac.nz (Member)
} 
characterisation, as has been completed for other regions in New Zealand. Wherever possible, guidance from similar regional studies was referred to so that a reasonably consistent approach was adopted across the country. The geologic setting of the Nelson-Tasman region is presented and the main contributors to the seismic hazard in the region discussed. The site investigation methodologies that are applied to a range of sites across the region to develop $\mathrm{V}_{\mathrm{S}}$ profiles and site period estimates are presented. An example site is explored in detail, and all data then collated for each of the predominant geologic formations. Representative $\mathrm{V}_{\mathrm{S}}$-depth models for each formation based on this data are developed, with these models compared with international reference models and other New Zealand regional models. These are discussed in the context of potential site amplification effects and site classification for seismic design.

\section{GEOLOGIC SETTING AND SEISMIC HAZARD OF THE NELSON-TASMAN REGION}

The Nelson-Tasman region is located in the north-west of the South Island of New Zealand shown in Figure 1. Basement rocks exposed immediately to the east of the Nelson urban area include Brook Street Volcanics Group of Permian age and Richmond Group Sedimentary rocks of Triassic age. The terranes were accreted at the Paleozoic-Early Cretaceous convergent margin of Gondwana prior to Late Cretaceous rifting (110-85 Ma), with opening of the Tasman Sea [26, 27]. These units have been exposed by uplift along the Flaxmore and Waimea Faults and dip steeply which is likely a consequence of a long history of superposed deformation [28].

The steep rocky mountain ranges that enclose the region have supplied huge volumes of gravel to the lower lying areas. Over time, the relatively flat areas of Nelson and Richmond have been formed on outwash gravels. In the Moutere Depression (Figure 1), an extensive area of Moutere Gravel Formation is preserved where it has been transported northwards from the Spenser Mountains [29]. Slightly weathered, well rounded quartzofeldspathic sandstone clasts in a brown weathered muddy sand matrix comprise the bulk of the Moutere Gravel. The gravels are described as uniform yellow-brown, claybound gravel, with deeply weathered clasts that are almost entirely of Torlesse-derived sandstone and semi-schist [30]. The unit underlies surficial Quaternary deposits in the suburbs of Richmond, Stoke and Tahunanui and crops out as ridges in
Richmond. Seismic reflection surveys carried out for petroleum exploration indicate the unit is likely to be $1-1.5 \mathrm{~km}$ thick beneath these suburbs. The Moutere Gravel is the youngest formation of the Tadmor Group and is late Pliocene to earlyPleistocene in age (Wopereis personal communication 2018).

The majority of the Nelson-Tasman sediments comprise unconsolidated sands, partly consolidated river gravels and minor areas of soft peat [30]. Alluvial gravels are widespread and well preserved in flood plains. The formations described in the following text are prominent across the Nelson-Tasman region and have been the focus of this regional study. Figure 2 is an excerpt from the study by Ghisetti et al. [28] with the prominent formations labelled. In Nelson city, the Port Hills Gravel formation is up to $500 \mathrm{~m}$ thick, consisting of granitic conglomerate grading upwards into conglomerate composed of clasts of volcanic Permian/Triassic rocks largely derived from the east of the Waimea Fault [31]. Port Hills Gravel is comprised of heterogeneous clay and silt-bound gravel/conglomerate with lenses of sandstone and occasional lignite seams and is intersected by a number of faults [32]. This unit is a clay-bound gravel in the near-surface but is transitional to rock, meaning that except where weathered, the matrix is more characteristic of a weak siltstone [33]. Port Hills Gravel is the oldest formation in the Tadmor Group and is late Miocene to early Pliocene in age. In Nelson City the unit is folded in two synclines, the Port Hills Syncline and the Marsden Syncline, separated by the Flaxmore Fault.

Alluvial gravels are widespread in the region and have been well preserved in the flood plains and aggradation surfaces. Large alluvial fans, screes and colluvial deposits are also prominent, generally found at the foot of steep streams, draining hills and ranges. These fans comprise poorly sorted, angular silt-to-boulder sized clasts and lack clear stratification. Marine and beach deposits (gravel, sand and mud) are preserved in areas of Golden Bay and around sea-level in the Tasman Bay. Sand dunes and marine sands exist along much of the coast of the Tasman Bay and Golden Bay. Swamp deposits are noted commonly on the landward side of beach dunes near river mouths or immediately upstream of recent landslides. Swamp deposits comprise poorly consolidated sand, mud and peat. There have also been a number of areas reclaimed in recent years with the use of hardfill and domestic rubbish to extend the natural foreshore area.

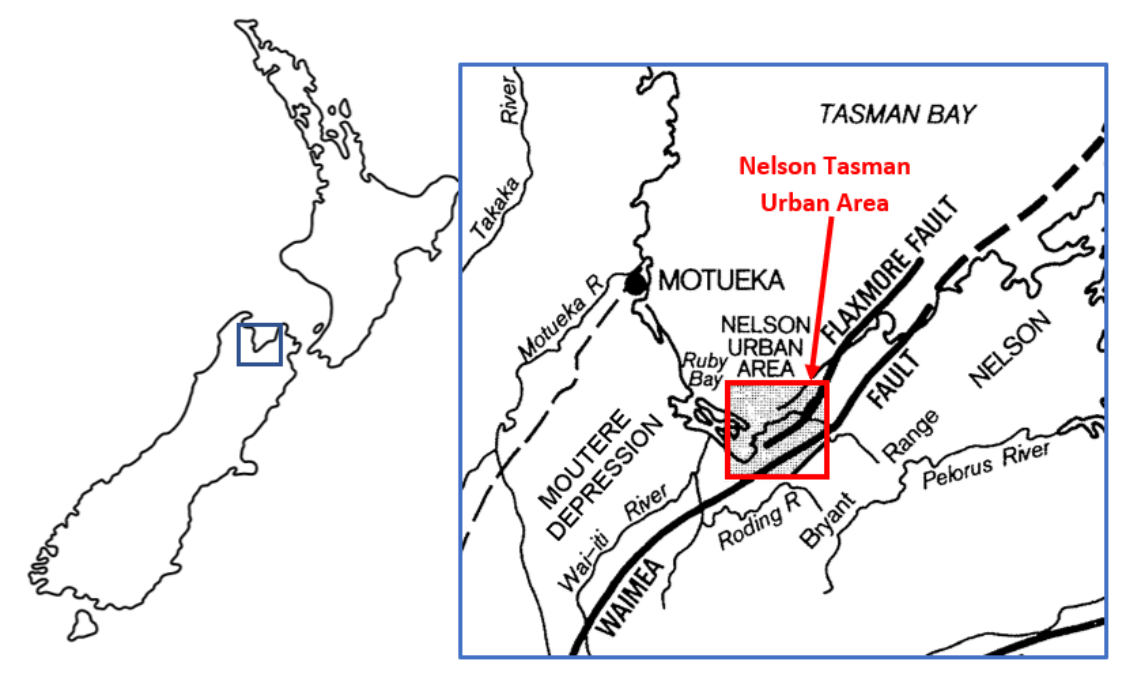

Figure 1: Location of Nelson-Tasman in New Zealand; Inset: Map showing the location of Waimea-Flaxmore Fault System relative to main urban areas of Nelson and Richmond (after [35]). 


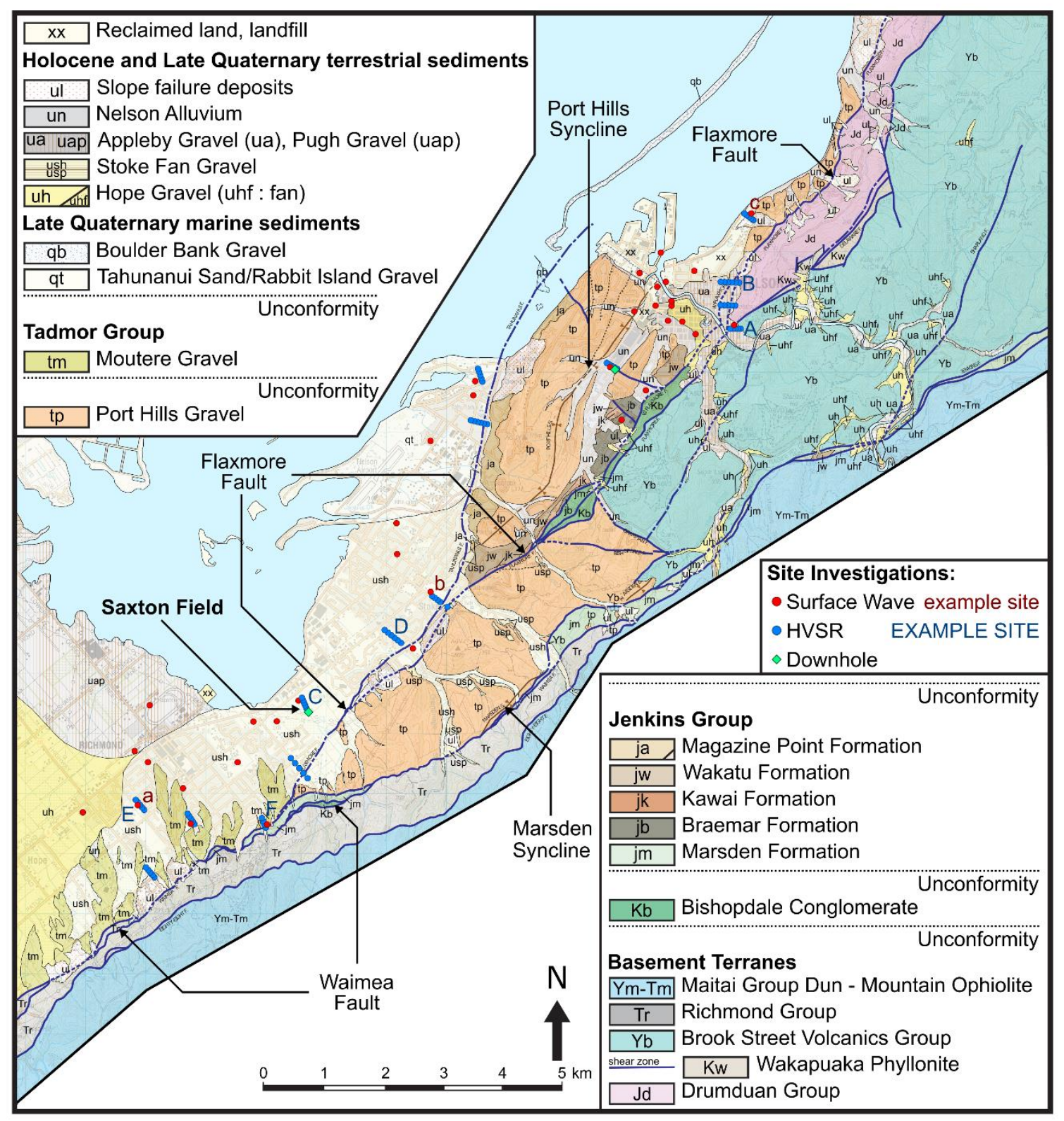

Figure 2: Simplified geological map of the Nelson-Richmond urban area and geophysical site investigation locations (Modified from [28]).

Recent Quaternary deposits in the Nelson-Tasman area include alluvial gravels and fan deposits, marine deposits, swamp deposits and sands [31]. Prominent formations including; Stoke Fan Gravel, Appleby Gravel, Hope Gravel, Nelson Alluvium and Tahunanui Sand, make up a vast majority of the surficial deposits in the region. These formations are the focus of the research presented in this paper and are discussed in more detail in later sections.

The Nelson-Tasman region is considered a 'moderately' seismic area in the context of NZ seismicity, due to the proximity to the Alpine Fault,the local Waimea-Flaxmore Fault System (WFFS) [29], and other regional faults, such as the Wairau Fault [34]. The Waimea-Flaxmore Fault System is a pronounced feature of the Nelson-Tasman area and extends for approximately $150 \mathrm{~km}$ north-east from the Alpine Fault near St Arnaud to the western side of D'Urville Island (crossing the Nelson region in Figure 1). The Moutere Depression is outlined in the area to the west of the Waimea Flaxmore Fault. The Nelson, Stoke and Richmond urban areas straddle the fault, which is generally between 1 and $5.5 \mathrm{~km}$ wide as expressed at the ground surface [35]. While there is a relatively long recurrence interval of approximately 6000 years [29], field mapping has provided evidence of rupture events indicating that this system is a seismogenic source capable of generating large magnitude earthquakes [35]. Large continuous Holoceneactive strands are documented along the southernmost part of the WFFS. The Alpine Fault is approximately $600 \mathrm{~km}$ long, runs along the length of the South Island of New Zealand, and it is capable of generating relatively frequent (approximately 330 year recurrence interval) and large magnitude ( $\mathrm{Mw} 8+$ ) event earthquakes [36]. The Nelson-Tasman region is likely to be impacted by an Alpine Fault event, with an estimated 68 to $75 \%$ probability of rupture in 50 years on the central section and 40 to $43 \%$ probability of rupture on the southern [37].

The Nelson-Tasman area is characterised by shallow seismicity $(<15 \mathrm{~km})$ largely concentrated in the west, an absence of middepth seismicity $(15-40 \mathrm{~km})$ and deep seismicity $(>40 \mathrm{~km})$ in central and eastern parts related to subducting Pacific Plate. The region has historically been impacted by a number of New Zealand's most notable earthquake events, including the 1848 M7.1 Marlborough Earthquake, 1893 M7.0 Nelson Earthquake, 
1929 M7.3 Murchison Earthquake and most recently the 1968 M7.5 Inangahua Earthquake.

\section{SITE INVESTIGATION METHODOLOGY}

A combination of geophysical site investigation methods were utilised at several locations (Figure 2) to improve understanding of dynamic site characteristics across the Nelson-Tasman region. These methods included surface wave, downhole seismic, and horizontal-to-vertical spectral ratio (HVSR) testing. Whenever possible, the geophysical data were processed and interpreted with constraint from a priori geotechnical and geological data. The resulting ground models (e.g., Vs profiles) coupled with regional geological knowledge were then used to develop inferred relationships for the subsurface ground profile.

\section{Surface Wave Testing}

Surface wave methods are non-invasive seismic geophysical testing methods that utilize the dispersive nature of surface waves to infer the layering and $\mathrm{V}_{\mathrm{s}}$ profiles underneath an array of sensors placed at the ground surface. Surface wave velocity changes as a function of frequency (or wavelength). At high frequencies (short wavelengths), the surface wave velocity is representative of the stiffness of the near-surface layers. As frequency decreases (wavelengths increase), the surface wave velocity generally increases as deeper, stiffer materials are "sampled" by the surface waves. To measure a wide frequency range of surface waves, this study employed a combination of active- and passive-source surface wave testing methods using $1 \mathrm{D}$ and $2 \mathrm{D}$ arrays of sensors, respectively.

The active source surface wave testing method used in this study was the multi-channel analysis of surface waves (MASW) [38, 39]. The active-source data was collected using a linear array of $244.5 \mathrm{~Hz}$ vertical geophones uniformly spaced either $2 \mathrm{~m}$ or $5 \mathrm{~m}$ apart, corresponding to an array length of 46 $\mathrm{m}$ or $115 \mathrm{~m}$, respectively. Rayleigh waves were generated from vertical strikes using either a $100 \mathrm{~kg}$ drop weight or (more commonly) a 12-pound $(5.4 \mathrm{~kg})$ sledge hammer. Multiple source offsets of $5,10,20$, and up to $40 \mathrm{~m}$ from the first geophone were utilised to identify and minimise near-source effects. At each offset, ten source strikes were recorded and stacked to improve the signal-to-noise ratio of the stacked waveforms.

The active-source MASW data were processed using the Frequency Domain Beamformer (FDBF) method [40]. Using the FDBF, an experimental dispersion curve was calculated for each source offset. The resulting dispersion curves were cleaned to remove spurious data and combined to develop a single composite active-source experimental dispersion curve.

For this study, the passive-source surface wave method used was the microtremor array measurement (MAM) method [41, 39], which requires sensors to be placed in a two-dimensional array to measure the ambient wavefield traveling across the site. The sensor arrays measure ambient vibrations for a period of time ranging from 30 to 60 minutes depending on the size of each array. The shape and size of the passive array was dictated by the spatial constraints of the site. Typically, a combination of an L-array and multiple circular arrays were employed for the measurement of mid- and low-frequency data, respectively. The L-arrays consisted of $244.5 \mathrm{~Hz}$ vertical geophones, spaced either two or five metres apart. The circular arrays consisted of up to ten three-component Trillium Compact 20 second broadband seismometers. One seismometer was placed at the centre of the circle, with the other nine evenly placed around the circumference of the circle. The circle diameters ranged from $50 \mathrm{~m}$ to $200 \mathrm{~m}$.
Regardless of array geometry and instrumentation, the Rayleigh wave dispersion data from the vertical component of the ambient noise records were computed using the HRFK method [42]. The ambient noise records were broken into 180 second time windows ensuring a sufficient number of cycles for each frequency in the dispersion analysis. A dispersion curve was computed for each time window. A single composite experimental dispersion curve for each passive sensor array was developed via the combination of the individual time window dispersion curves.

At each site, a combination of MASW, L-array and/or circular array testing was employed and an experimental dispersion curve was computed for each array. All of the experimental dispersion data was combined into a single composite dispersion curve representative of the soil/rock profile at the site. The dispersion data was binned in the frequency domain (30 points logarithmically-spaced between 0.1 and $60 \mathrm{~Hz}$ ). A mean and standard deviation Rayleigh wave phase-velocity was computed for each bin to be used in the inversion analysis. The combination of multiple surface wave testing methods is robust, as each method provides resolution of surface waves at different frequencies (or wavelengths) corresponding to different depths of the geologic profile. The active-source MASW excites and measures the highest frequency surface waves, providing resolution of materials at the near-surface. Conversely, the circular arrays are best suited to measure ambient vibrations at low frequencies, enabling the resolution of deeper materials. The passive L-array testing data fills in the mid-range frequencies.

The Dinver module of the open-source software package Geopsy [43] was used to perform an inversion of the experimental dispersion data for each site. Surface wave inversion is an ill-posed problem; the experimental dispersion curve data (Rayleigh wave phase velocity and frequency) are fitted with theoretical dispersion curves forward modelled from input of the inferred 1D geological profiles with four variables (layer thickness, $V_{S}, V_{P}$, and mass density). Furthermore, the solution to this problem is non-unique; hundreds of thousands of possible ground profiles are considered in each inversion, and any of those that sufficiently fit the experimental data may be representative of the "true" ground profile at the site. For each considered ground model, a theoretical dispersion curve is calculated via forward modelling. The forward model calculations were originally developed by Thomson [44] and Haskell [45] and later modified by Dunkin [46] and Knopoff [47].

The fit of the theoretical dispersion curves to the experimental data was evaluated using a dispersion misfit equation [48]:

misfit $=\sqrt{\frac{1}{n_{f}} \sum_{i=1}^{n_{f}} \frac{\left(x_{e i}-x_{t i}\right)^{2}}{\sigma_{i}^{2}}}$

where $\mathrm{n}_{\mathrm{f}}$ is the number of frequencies considered in the target experimental dispersion data. At a given frequency $f_{i}, x_{e i}$ is the mean phase velocity of the experimental dispersion data, $x_{t i}$ is the phase velocity theoretical dispersion data, and $\sigma_{i}$ is the standard deviation of the experimental dispersion data. The calculated misfit value is dependent on the experimental dispersion data being fitted, thus these values can only be used to evaluate the relative misfit of a theoretical dispersion curve to a specific experimental dispersion curve target. The misfit values cannot be used to quantitatively compare the inversion results between different inversion targets (e.g., surface wave data from different sites).

The inversion process is constrained by defining an initial layered parameterisation consisting of velocity $\left(\mathrm{V}_{\mathrm{S}}\right.$ and $\left.\mathrm{V}_{\mathrm{P}}\right)$, boundary depth or layer thickness, Poisson's ratio, density, and the number of layers in the soil profile. The dispersion curve forward modelling is most sensitive to layer depth/thickness 
and Vs. Each of these parameters are allowed to vary over reasonable ranges, i.e., layer depth/thickness and $V_{s}$ are not fixed. For each inversion run, the Dinver neighbourhood algorithm searches the prescribed parameter space to generate tens to hundreds of thousands of theoretical ground models. For each ground model considered by the inversion algorithm, a single fixed $V_{S}$ is assigned to each soil layer. In cases of thick soil layers, the parameterisation is adjusted to include sublayering to allow for the gradual increase in $\mathrm{V}_{\mathrm{S}}$ with increasing confinement. The thickness and number of sub-layers depends on the site, thickness of the main layer, and observations in inversion trends.

Whenever possible, a priori geotechnical and geological data from site investigations (e.g., boreholes, CPT, and geologic mapping) was used to constrain and inform the initial parametrisation and limit the searchable solution space from which the ground models may be generated. For example, reasonable ranges of $\mathrm{V}_{\mathrm{S}}$ were defined based on soil type. Layer boundaries were never fixed, rather they were allowed to vary at least $\pm 1 \mathrm{~m}$ to allow for lateral changes across the site. These thickness/depth constraints were relaxed as: (1) the distance to nearest a priori data increased, (2) the layer depth increases, reflecting the lack of deep site characterisation, and (3) as inversion parameterisations were adjusted/improved to improve the fit of the theoretical dispersion curves to the experimental data.

In cases where a priori information was unavailable or insufficient to constrain the layering at deep passive testing sites, a layering ratio approach of Cox et al. [49] was adopted to define an initial parameterisation and limit the solution space. The basis of this method is an iterative approach where the layering ratio is systematically varied to develop a suite of considered parameterisations. The layering ratio is a multiplier that increases the potential thickness of each layer relative to that of the layer above it. By using this layering ratio value within a specified range (usually a value between 1.2 and 5) it is possible to identify and encompass the most reasonable layering model, even without a priori information to constrain the inversion. The minimum inversion misfit value for each layering ratio parameterisation is used to identify the suite of models which can best match the experimental dispersion curve data. It should be noted that while this is the 'best fit' for the experimental curve, it is not necessarily the best representation of the true layered ground model at the site. Thus, often a mix of low misfit value layering ratios are included in the suite of 'best' ground models for a site without a priori site investigation data. For this study, the layering ratio approach was used to systematically explore deep layering parameterisations at five sites: Miayazu Park, Nayland College, Ngawhatu Park, Richmond Racecourse and Tahunanui Fields. The 'best'layering ratio parameterisations were refined using shallow geotechnical site characterisation data to further constrain the near surface layering.

For each of the 29 Nelson-Tasman sites, several parameterisations and hundreds of thousands of potential ground models were considered in the inversion process. As a means to capture the uncertainty associated the $\mathrm{V}_{\mathrm{S}}$ profiles, current best-practice encourages the use a suite of ground models that adequately fit the 'site signature' of high-quality experimental surface dispersion data $[51,52,39]$. For each of the 29 sites considered in this study, the 1000 'best' ground models with lowest misfit to the experimental dispersion data were kept for subsequent analyses.

\section{HVSR Testing}

The horizontal-to-vertical spectral ratio (HVSR) testing method, also called H/V or Nakamura's method, is used to estimate the fundamental site period based on single-station ambient vibration recordings. In this study, Nanometrics Trillium Compact 20 second broadband seismometers were used to measure ambient vibrations. The seismometers were placed in a hole 100-150 mm deep and then surrounded by tightly compacted soil or placed on a levelling cradle on a solid surface, and protected from wind-gusts by placing a weighted container over the sensor unit. Ambient vibrations were recorded at each site for a duration of 30 to 60 minutes and a sampling frequency of $100 \mathrm{~Hz}$ was used for all test locations. These records were processed using the HVSR method, as per the SESAME [52] guidelines and methodology. Each record was broken into 180 second-long windows. For each window, the three-component recording was transformed into the frequency domain, the geometric mean of the two horizontal components was computed, and the ratio of the averaged horizontal components and the vertical component was evaluated. Time windows with localised transient noise or outliers were removed. The remaining time windows were averaged to develop a representative HVSR curve for the site. A well-defined peak in the HVSR data can be used to infer (1) the fundamental site period for the entire soil profile down to bedrock (a significant impedance contrast); or (2) the natural period of the soil profile above a shallower impedance contrast [53].

\section{Downhole Seismic Testing}

Downhole seismic testing was completed at two site locations in Nelson-Tasman where a shear plank was offset a short distance at the ground surface and a string of multiple geophones were lowered incrementally down into a cased borehole. The general procedures were in line with the ASTM test standard approach [54]. Picking of the shear wave arrival at each test depth was based on the first arrivals. The downhole data was processed using the 'slope-based' method [55-57]. The vertical wave travel time was plotted against depth and the gradient of the trendline was used to approximate the $V_{S}$ with depth. At locations on the plot where the gradient trendline changed, a change in the subsurface material (at least in terms of $V_{S}$ properties) can also be inferred.

\section{SITE CHARACTERISATION RESULTS}

A total of 29 sites across the urban areas of Nelson, Tahunanui, Stoke and Richmond were selected for this study. At all these locations active source surface wave testing was carried out. At all of these sites passive source methods were also performed, using a combination of circular arrays and L-arrays. HVSR measurements were then collected at all of these sites and at an additional 23 locations to characterise the broader variability in site period across the region. The testing locations are summarised in Figure 2.

The HVSR testing generally found that there was likely an insufficient impedance contrast between the bedrock and overlying materials to produce clearly identifiable peaks in the HVSR data that would provide estimates of the fundamental site period. The results of this testing is briefly summarised in the following section.

A surface wave testing case history is presented to demonstrate the site investigation process and the development of $V_{S}$ profiles. Saxton Field was chosen as a case study as there were several surface wave testing arrays and the results are compared with a $\mathrm{V}_{\mathrm{S}}$ profile from downhole shear wave testing. Following this discussion, the surface wave testing results at three additional sites are presented. Finally, the shear wave velocities from prominent geologic formations across the region are combined and their characteristics as a function of depth discussed. 

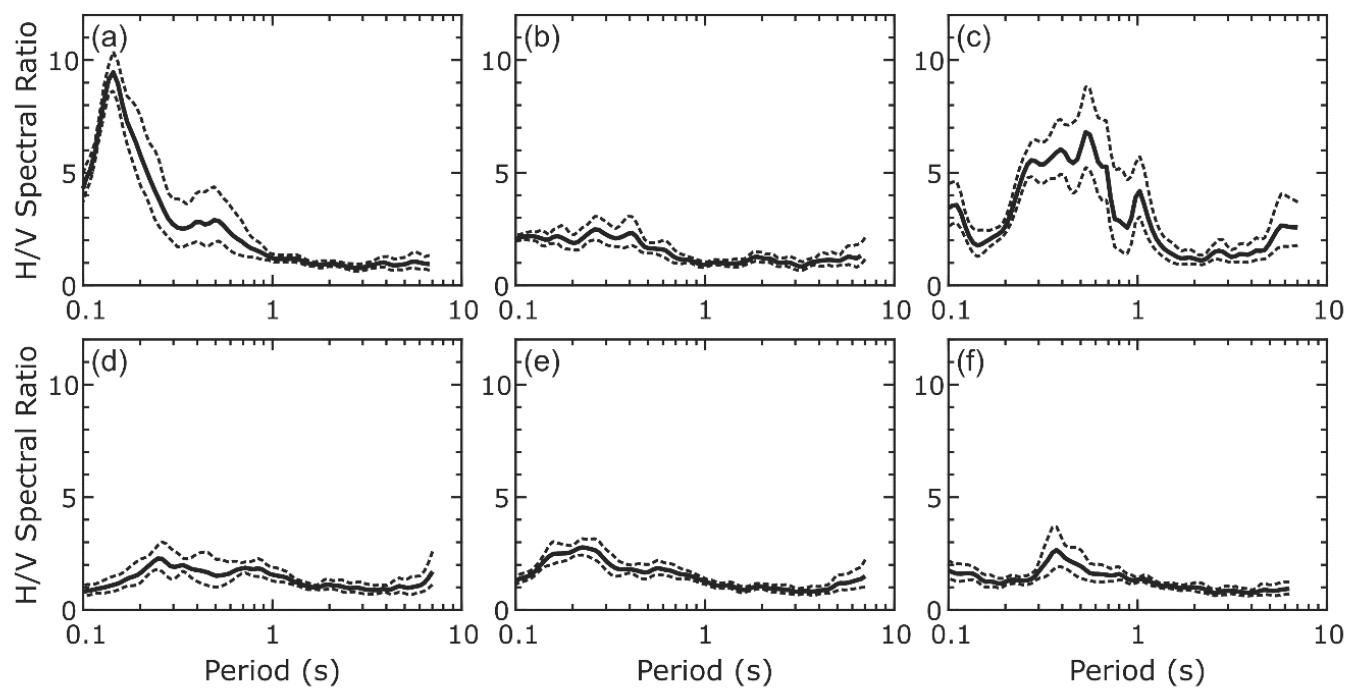

Figure 3: Typical Nelson and Tasman HVSR curves from testing at six sites: (a) Botanical Garden, (b) Cambria Street, (c) Saxton Field, (d) Manson Avenue, (e) Ben Cooper Park and (f) Easby Park.

\section{HVSR Testing Results}

HVSR testing was performed at 52 sites to explore trends in the fundamental period of vibration of soil above bedrock across the Nelson and Tasman region. The results of HVSR testing at six example sites are presented in Figure 3. The locations of these sites are indicated by blue uppercase letters on the geologic map in Figure 2: (A) Botanical Garden, (B) Cambria Street, (C) Saxton Field, (D) Manson Avenue, (E) Ben Cooper Park, and (F) Easby Park. At a sites underlain by shallow, stiff bedrock (e.g., the Brooks Street Volcanics Group) a single clear, short-period HVSR peak likely indicates the fundamental period of vibration of soft soils above the bedrock, such as at the Botanical Garden (Figure 3a) in Nelson. At many study sites in the region, clear peaks passing the SESAME criteria [52] were not observed in the HVSR curves (e.g., Figure 3 b-f). A strong impedance contrast between soils and underlying rock is necessary to create a clear HVSR peak. Across much of the Nelson-Tasman region, dense near-surface gravel deposits are dominant. These stiff gravels coupled significant depth to bedrock and a complex geologic setting are inferred to produce weak impedance contrasts and unclear HVSR peaks. For this reason, the HVSR site period estimates have not been presented in this paper.

At some sites, surficial alluvial fan gravels are underlain by stiffer, older gravels producing a broad unclear peak, such as that observed at Saxton Field (Figure 3c). This site is further discussed in the following section.

\section{Case Study Site - Saxton Field}

Saxton Field is a sporting and recreational area in Stoke, which is part way between Richmond and Nelson City. The site is located approximately $300 \mathrm{~m}$ from the estuary coastline to the north, with the Richmond Ranges rising steeply to the south of the site. The surface wave testing completed at Saxton Field included active MASW and passive MAM. The passive testing included two circular arrays (50 and $100 \mathrm{~m}$ diameters) and a 55 $\mathrm{m}$ by $60 \mathrm{~m} \mathrm{~L}$-array. The testing locations and array geometry are summarised in Figure 4. In addition to the surface-wave testing, a $30 \mathrm{~m}$ deep borehole was drilled to collect factual geotechnical data and to perform downhole seismic testing. This site was chosen to target the Moutere Gravel formation which underlies a significant proportion of the developed areas in Richmond, Stoke and Tahunanui.

The surface wave inversion using the combined experimental dispersion curve was carried out using parameterisation limited to a depth of $100 \mathrm{~m}$. The maximum depth of characterisation was constrained by the geometry of the testing arrays. The published geological information and nearby geotechnical data collated for this study, coupled with insights gained from the downhole seismic testing were used to inform the parametrisation for the surface wave inversions. The observed stratigraphy in the borehole log and the velocities from the downhole testing provided a starting point in the development of the shallow parameterisation. However, layering boundaries and velocities were assigned reasonable ranges to accommodate variation of material properties across the site and underneath the horizontal extent of the surface wave instrumentation arrays. For this site, the inversion parametrisation was adjusted several times based upon the intermediate inversion results, striking a balance between adequately considering the available priori information and preventing the over constraint of the inversion. For the final parameterisation, over 60,000 ground models were generated by the inversion neighbourhood algorithm. The 1000 'best fit' ground models with the lowest misfit to the experimental dispersion data, as evaluated using equation 1 , were extracted.

The experimental dispersion curve and 1000 'best fit' theoretical dispersion curves are presented in Figure 5a. The Rayleigh wave velocity $\left(V_{R}\right)$ error bars represent the range of the experimental data for each frequency bin. At lower frequencies, the error bars are larger indicating the increased variability and decreased resolution of material properties at depth. The corresponding 'best fit' $V_{s}$ profiles are plotted with depth in Figure 5b. The single best fit profile is indicated by thick solid line, the best 50 profiles indicated by dark grey lines, and the light grey lines indicate the 1000 best $V_{S}$ profiles. 


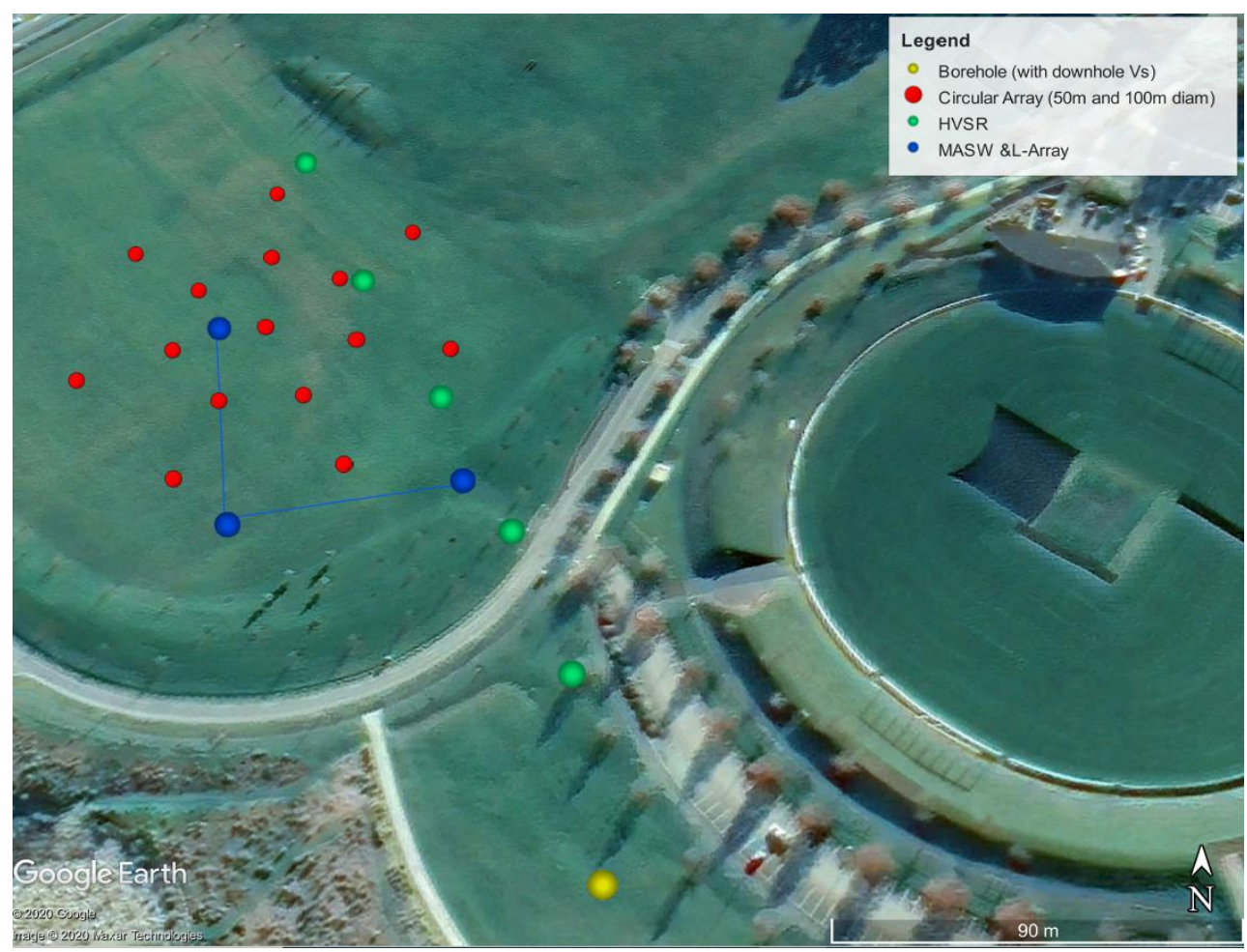

Figure 4: Aerial view of Saxton Field geophysical testing locations, highlighting the location of arrays for active and passive source methods, and the borehole location.
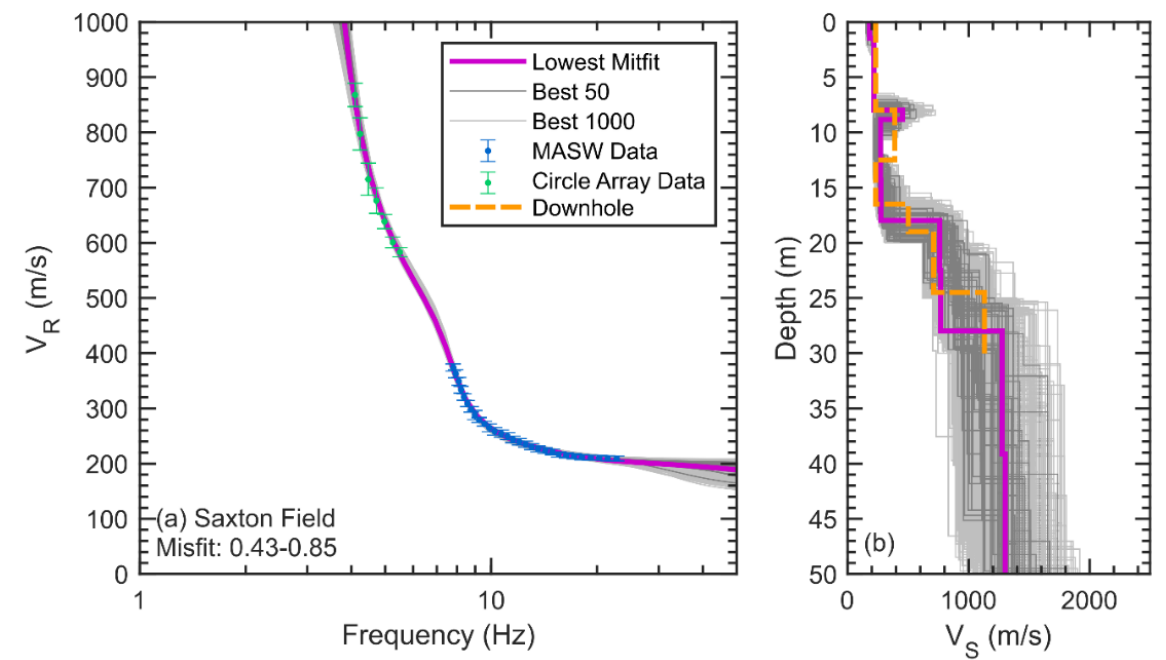

Figure 5: Saxton Field surface wave data: a) experimental dispersion curve and 1000 'best fit' theoretical dispersion curves; b) 1000 'best fit shear wave velocity profiles and the profile from downhole testing.

The downhole Vs profile (dashed line) is shown in Figure $5 \mathrm{~b}$ with the surface wave inversion results for comparison. While the parametrisation of the surface wave inversion was developed using insights gained from the downhole seismic testing, the general trends in Vs to a depth of 25 metres indicate general agreement between the two methods and lend confidence to the surface wave testing at depth. The downhole data identified the relatively high $\mathrm{V}_{\mathrm{s}}$ of the underlying Moutere Gravel. A Vs of up to and above $1000 \mathrm{~m} / \mathrm{s}$ was not expected for the clay-bound gravel deposits in the region, however the downhole testing confirms that this is likely to be representative for the Moutere Gravels as it shows $\mathrm{V}_{\mathrm{S}}>1000 \mathrm{~m} / \mathrm{s}$ within $30 \mathrm{~m}$ below ground level.

A layer of 'swamp derived' deposits was encountered between the upper 10-15 m (below ground level) of Stoke Fan Gravel, and the underlying Moutere Gravel Formation. The swamp deposits encountered at Saxton Field were generally soft silt/clay with wood fragments. This material was sampled and subjected to geological dating tests. These indicated that the deposits were older than Holocene age, and therefore were separate to the Stoke Fan Gravel Formation. An indicative age of approximately 52,000 years was estimated based on pollenbased dating methods (completed by Massey University), which is younger than the Port Hills Gravel or Moutere Gravel formations that underlie the identified swamp deposits.

It was expected that the $V_{S}$ of the soft swamp material would be lower than the Stoke Fan Gravel or Moutere Gravel formations on either side. As can be seen from the layered profile, the $\mathrm{V}_{\mathrm{S}}$ increases to $390 \mathrm{~m} / \mathrm{s}$ at a depth of $7 \mathrm{~m}$ before dropping back to around $230 \mathrm{~m} / \mathrm{s}$ at the depth where the swamp deposits were likely to be encountered. This inference was confirmed through the downhole testing which provided a 
similar $V_{s}$ in this depth range. Below the swamp deposits are the highly weathered Moutere Gravel, which has a rapid increase in $V_{S}$ with depth. It was noted that based on subsurface information from the surrounding area, the depth to the swamp deposits overlying the Moutere Gravel was likely to be variable, therefore the depth and thickness of this layer was not completely constrained in the surface wave inversion. Instead, the parameterisation allowed a layer around that approximate depth to have a lower $\mathrm{V}_{\mathrm{S}}$ than the layer above.

The softer layer in the surface wave $\mathrm{V}_{\mathrm{s}}$ profiles is thinner and shallower than observed in the geotechnical borehole and downhole data. This is reasonable due to the lateral variability of the deposits in the area, and likely differences between the locations of the borehole and surface wave testing arrays.

The misfit values of the 1000 best ground models ranged from 0.43 to 0.85 . Quantitatively, the lowest misfit value theoretical dispersion curves are closer to the mean phase velocity values of the experimental dispersion curve. However, as shown in
Figure 5a all of the 1000 'best fit' theoretical dispersion curves fall within uncertainty bounds of the experimental data. In aggregate, the 1000 'best fit' models capture the experimental and modelling uncertainty, carrying this uncertainty into the ground models. At the near-surface, there is minimal scatter in the ground models, in terms of both velocity and boundary depths between layers. This is due to the narrow, well-defined range of experimental dispersion data at high frequencies. At depths greater than 15 metres, there is increased scatter in the $V_{s}$ profiles reflecting both the increased uncertainty in the lowfrequency experimental dispersion data and the lateral variability of materials across the extent of the passive instrument arrays. Despite apparent scatter in suites of nonunique $\mathrm{V}_{\mathrm{s}}$ profiles from surface wave testing, Teague and Cox [50] note that if the 'site signature' (e.g., experimental dispersion curve) is matched, then the resulting site response analyses are accurate with minimal variability.
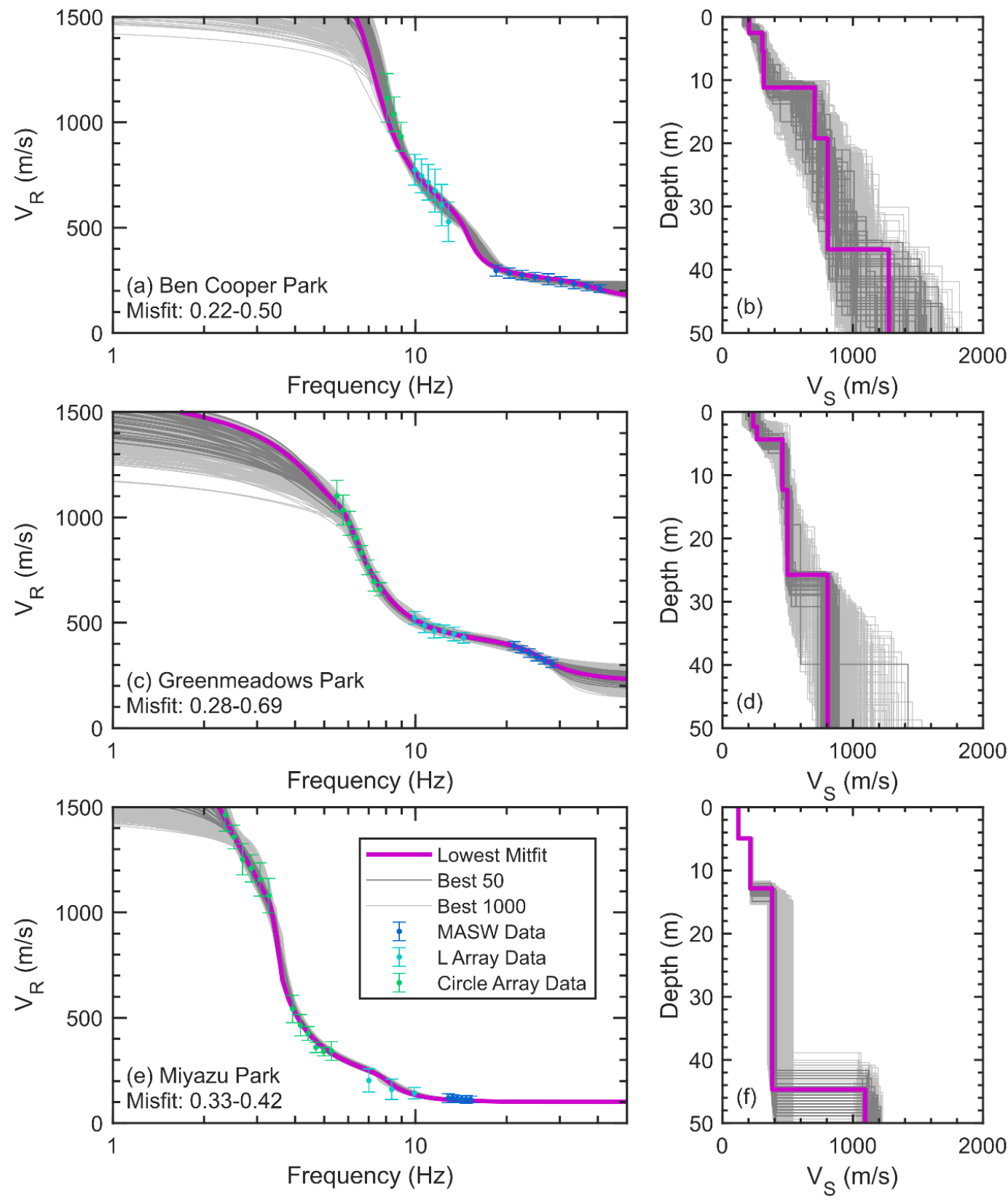

Figure 6: Example surface wave testing results. (left) A comparison of experimental dispersion data and the 1000 best fit theoretical dispersion curves and (right) the 1000 'best fit' VS profiles at Ben Cooper Park (a \& b), Greenmeadows Park (c \& d) and Miyazu Park $(e \& f)$. 
As the surface wave forward modelling problem is ill-posed and the solutions are non-unique, the current best practice is to consider a suite of ground models that adequately fit the experimental dispersion data and account for the uncertainty in the resulting Vs profiles [50, 51, 39]. Each of the 1000 'best fit' models could be directly used in the subsequent analyses, as is done in the development of the $\mathrm{V}_{\mathrm{S}}$-depth models below. Alternatively, a median $\mathrm{V}_{\mathrm{S}}$ profile and lognormal standard deviation could be evaluated with depth. Any $V_{s}$ profiles derived from these statistics should be evaluated for misfit to the experimental dispersion curve [51].

\section{Additional Surface Wave Testing Results}

Surface wave testing was performed at 29 sites, including Saxton Field, in the Nelson and Tasman region. At 15 of these sites, passive-source MAM testing using L- or circular-shaped sensor arrays was perfumed to achieve greater $V_{S}$ profiling depths. Presenting the individual results from all of these sites is beyond the scope of this paper. However, the experimental dispersion data, the theoretical dispersion curves, and the 1000 best inversion ground models are presented for three example sites in Figure 6. The locations of the (a) Ben Cooper Park, (b) Greenmeadows Park, and (c) Miyazu Park sites are indicated by red lowercase text in Figure 2. Based on available geotechnical data and regional geological knowledge [28-34], near-surface layers in the Vs profiles were attributed soil deposits. At Ben Cooper Park (refer to Figure 6b), the nearsurface $(0-11 \mathrm{~m})$ Stoke Fan Gravel is underlain by the Moutere Gravel. At Greenmeadows Park (refer to Figure 6d), the Stoke Fan Gravel $(0-25 \mathrm{~m})$ is underlain by the Moutere Gravel. At Miyazu Park (refer to Figure 6f), the Nelson Alluvium (0-12 m) is underlain by the Port Hill Gravels.

\section{SHEAR WAVE VELOCITY OF REGIONAL DEPOSITS}

To identify broad regional trends in the Vs characteristics across the prominent geologic formations, the $\mathrm{V}_{\mathrm{s}}$ profiles from each test site were assigned to a geologic formation for the respective depth ranges at each testing location. Within these depth ranges, the $1000 \mathrm{~V}_{\mathrm{S}}$ profiles were extracted, discretised into metre-thick layers, and subsequently combined and organized by geologic formation to develop regional representative $V_{S}$ profiles. Instead of showing tens of thousands of individual $\mathrm{V}_{\mathrm{S}}$ points, the combined, representative $\mathrm{V}_{\mathrm{S}}$ profiles are indicated by modified box-and-whisker plots at metre-depth increments in Figure 7. The vertical line within the box indicates the median $\mathrm{V}_{\mathrm{S}}$ value, the bounds of the box indicate the 16th and 84th percentile $\mathrm{V}_{\mathrm{S}}$ values, and the whiskers indicate the 5th and 95th percentile Vs values. Thus, wide box-and-whisker plots indicate a large range in the $\mathrm{V}_{\mathrm{S}}$ at the associated depth, reflecting the lateral variability materials within each formation. Figure 7 summarises these details for each of the selected regional geologic formations. Each formation composite $\mathrm{V}_{\mathrm{S}}$ profile includes data from three to ten sites. However, the number of sites contributing to an individual box-and-whisker in certain depth ranges varies. In some cases a single site may be contributing, such as for the Port Hill Gravel formation between 6 and $12 \mathrm{~m}$. Thus, strong steps in the median Vs values and changes in box-and-whisker width is most often indicative of changing inclusion or exclusion of sites from the composite formation $\mathrm{V}_{\mathrm{S}}$ profile.

The Moutere Gravel formation is generally 10-100 $\mathrm{m}+$ below ground level, with the $\mathrm{V}_{\mathrm{S}}$ estimates for Moutere Gravel varying between $400-1000 \mathrm{~m} / \mathrm{s}$ with depth. These are relatively high
Vs values, especially given that Moutere Gravel is uncemented and clay-bound.

The $V_{S}$ for the Port Hills Gravel formation varied from $500-$ $800 \mathrm{~m} / \mathrm{s}$ in the upper $35 \mathrm{~m}$ which is inferred to most likely be the weathered clay-bound gravel material. Even these shallow deposits of Port Hills Gravel have relatively high Vs values. Data from three sites is included the composite Port Hills Gravel Vs profile. At two of these sites the shallow soil layers are attributed to the Nelson Alluvium, with layer boundaries at $13 \mathrm{~m}$ for one site and $15 \mathrm{~m}$ for the other. Steps in the median $\mathrm{V}_{\mathrm{S}}$ and broadening of the box-and-whisker plots indicate the inclusion of data from these sites.

The Stoke Fan Gravel formation covers a significant portion of the considered study area. The range of Vs for Stoke Fan Gravel formation was estimated to be between $200-500 \mathrm{~m} / \mathrm{s}$. There is a reasonable amount of spread within this data set, particularly between $10-15 \mathrm{~m}$ depth. This is inferred to be a result of the significant variability of the Stoke Fan Gravels, with some layers being largely gravel dominated, and others with a higher proportion of fine-grained material. Hope Gravel is a formation mapped in areas of Richmond and Nelson. It is described as a poorly sorted, tight clay bound gravel with some lenses of well sorted gravel [31]. The Hope Gravel $V_{S}$ is $300-400 \mathrm{~m} / \mathrm{s}$ depending on the depth and location of the deposit. There were relatively few testing locations thought to be founded on Hope Gravels. This is likely the reason for the relatively tight range of $\mathrm{V}_{\mathrm{s}}$ values for this deposit presented in Figure 7.

Tahunanui Sand is a relatively young deposit of Holocene age that is mapped as a widespread unit over the Tahunanui area in Nelson [31]. The published geological description is 'Sand forming beach ridges and dunes; local estuarine and swamp deposits'. Below 5 metres, the Vs of the Tahunanui Sand is approximately $200 \mathrm{~m} / \mathrm{s}$ based on surface wave testing at three sites.

Nelson Alluvium is a prevalent shallow formation of Pleistocene age across the urban area of Nelson City, comprising poorly sorted, and highly variable clay rich sediments (clay to silty or sandy clay) [30]. The $\mathrm{V}_{\mathrm{S}}$ varied between $200-400 \mathrm{~m} / \mathrm{s}$ down to a depth of $35 \mathrm{~m}$ below ground level. Much of the Nelson alluvium in central Nelson is derived from Port Hills Gravel and it is likely the Nelson Alluvium material at depth is a medium dense clayey gravel material, supporting the $\mathrm{V}_{\mathrm{s}}$ as high as $400 \mathrm{~m} / \mathrm{s}$. Data from seven sites was included in the composite Vs profile, however, data from only a single site is present at depths greater than 16 metres. This is reflected in the transition and narrowing of the composite $V_{S}$ profile box-and-whiskers over the depth range between 12 and 16 metres. The wider range of $V_{S}$ values at the near surface illustrates the lateral variability of the formation.

\section{Shear Wave Velocity-Depth Models}

As noted by Lin et al. [58], for a given soil deposit, the relationship between $V_{S}$ and the mean effective stress normalized by one atmosphere of pressure (normalised mean effective stress) can be represented using a first order powerlaw function. This is described by the following generalized functional form:

$V s=A_{s}\left(\sigma_{m}^{\prime} / P_{a}\right)^{n_{s}}$

where $A_{s}$ is the $\mathrm{V}_{\mathrm{S}}$ corresponding to a mean effective stress of 1 atmosphere $\left(P_{a}=101.3 \mathrm{kPa}\right), n_{s}$ is the normalised mean effective stress exponent and $\sigma_{m}^{\prime}$ is the mean effective stress. 


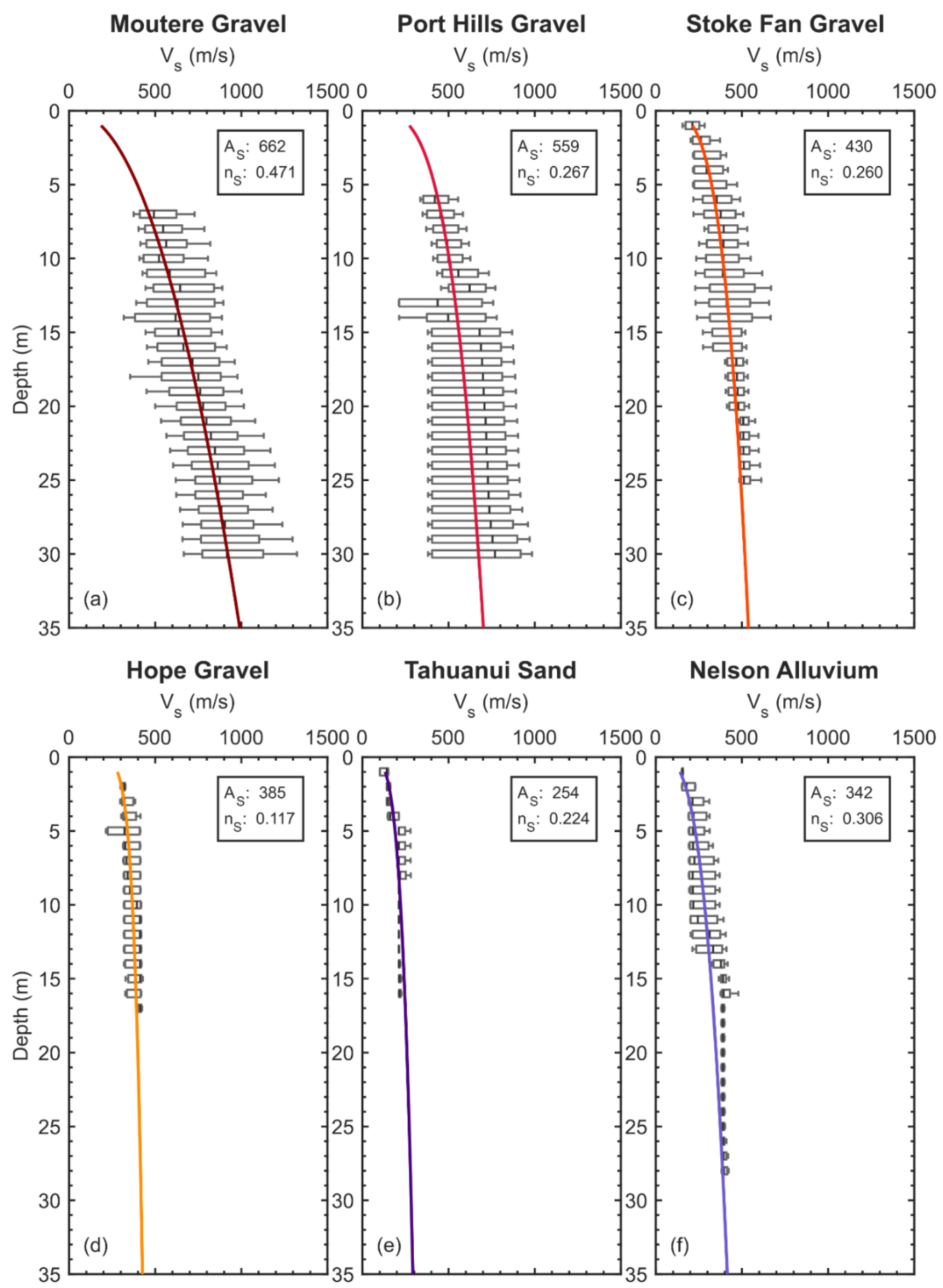

Figure 7: Box and whisker plots of the shear wave velocity with depth for the selected geologic formations and the corresponding $V_{S}$-depth models.

To develop $\mathrm{V}_{\mathrm{s}}$-depth models for Nelson/Tasman formations, the mean effective for each soil type was evaluated as a function of depth by assuming reasonable values for the unit weight of the soil, the at-rest lateral earth pressure coefficient, and depth to groundwater table. The unit weight was assumed for each soil based upon typical values in the literature [59]; $18 \mathrm{kN} / \mathrm{m}^{3}$ was assumed for the Tahunanui Sand and Nelson Alluvium formations, and $20 \mathrm{kN} / \mathrm{m}^{3}$ was assumed for the Moutere Gravel, Port Hills Gravel, Stoke Fan Gravel and Hope Gravel formations. The at-rest lateral earth pressure coefficient is dependent upon a variety of factors, including shear strength and stress history, however, 0.5 is commonly assumed in geotechnical practice for simple calculations [59]. For simplicity, the ground water table was assumed to be at the ground surface, but will vary site-to-site. The regional representative $V_{s}$ profiles summarised in Figure 7 were used to develop $\mathrm{V}_{\mathrm{S}}$-depth models for each geologic unit. The fitted relationships are indicated by the solid line in Figure 7 for each deposit, and the associated best-fit parameters, $A_{S}$ and $n_{s}$, are tabulated in Table 1.

The best-fit parameters for Equation 2 from the studies of Menq [60], Lin et al. [58] and Deschenes et al. [16] are also summarised in Table 1 for comparative purposes. The Menq study developed models for generic dense gravel and dense sand, and the Lin et. al. study developed models for Imperial Valley soft sands, silts and clays. The Vs-depth models are constrained based on the composition of the soil deposits in 
terms of grain size distribution and relative density. As this information is not currently defined for the Nelson-Tasman formations, these effects are not able to be assessed, and instead these generic comparisons are made. The Deschenes et al. study developed models for deposits in the Canterbury Plains region of New Zealand. These were developed for sites where gravels were present from the ground surface, for sites where interbedded gravel and sand/silt deposits were present, and for interbedded softer sands and silts.

Figure 8 compares the $\mathrm{V}_{\mathrm{s}}$-depth models from the NelsonTasman region with the other studies summarised in Table 1 . Figure 8a compares the Port Hills Gravel and Moutere Gravel models with the gravel deposit models from Menq [60] and Deschenes et al. [16]. The $\mathrm{V}_{\mathrm{S}}$ of both Nelson-Tasman deposits are significantly greater than the Dense Gravel model from Menq and the Canterbury Interbedded Gravels from Deschenes et al. over the entire depth range presented. The Port Hills Gravel and Moutere Gravel deposits have a Vs to around $15 \mathrm{~m}$ depth that are comparable to the 'Canterbury gravel only' deposits. Below this depth, the Nelson-Tasman deposits exhibit a more rapid increase in $\mathrm{V}_{\mathrm{S}}$ with depth.

In Figure $8 \mathrm{~b}$ the models for the Nelson-Tasman Hope Gravel and Stoke Fan Gravels are compared against the three gravel models from the literature. The Hope and Stoke Fan Gravel deposit relationships sit between the 'gravel only' and 'interbedded gravel' deposit relationships from Deschenes et al. Figure 8c compares the Tahunanui Sand and Nelson Alluvium deposits with the Lin et al. [58] 'Dense sand' and Deschenes et al. [16] 'soft soils' models. The Nelson-Tasman deposits have a slightly higher $\mathrm{V}_{\mathrm{S}}$ through the depth range presented.

\section{DISCUSSION}

\section{Shear Wave Velocity-Depth Models}

In general, the $\mathrm{V}_{\mathrm{S}}$ of the Nelson-Tasman deposits is high at relatively shallow depths. One possible explanation discussed in previous sections is that the Nelson-Tasman region is thought to have undergone cycles of geological uplift and subsidence, producing much denser, over-consolidated units that are likely to have relatively high Vs. Additional geotechnical characterisation of these regional deposits could help to confirm this, beyond the high $\mathrm{V}_{\mathrm{s}}$ measured here.

The Moutere Gravel and Port Hills Gravel formations have Vs exceeding $750 \mathrm{~m} / \mathrm{s}$ within a depth of $30 \mathrm{~m}$ below ground level. The high $\mathrm{V}_{\mathrm{S}}$ inputs from the Moutere Gravel results in both $A_{s}$ and $n_{s}$ coefficients that are much higher than that of the Menq [60] and Deschenes et al. [16] studies. The $V_{S}$ of Moutere Gravel is high for a clay-bound gravel, with Vs comparable to engineering bedrock. However, as Moutere Gravel has an unconfined compression strength (UCS) of less than $1 \mathrm{MPa}$, it should not be considered as such. For the purposes of coefficient comparison, only the inferred weathered or 'soillike', portion of the Port Hills Gravel was included in the development of the modelled $V_{S}$ equation coefficients. Even with data-points selected only from the depths that are expected to be a clay-bound gravel, it is noted that the $\mathrm{V}_{\mathrm{s}}$ coefficients are still higher than those of Menq 'Dense Gravel'.

Stoke Fan Gravel, Hope Gravel and Nelson Alluvium are all relatively young deposits that would not generally be classified as a 'dense gravel'. Therefore, the similarity between these units and the Menq Dense Gravel model is likely controlled by the effects of overconsolidation.

Table 1: Vs-depth model coefficients for Nelson-Tasman geologic deposits and coefficients developed from studies in other regions.

\begin{tabular}{|c|c|c|c|}
\hline Soil Type & $\begin{array}{l}\text { Estimated unit weight } \\
\qquad\left(\mathrm{kN} / \mathrm{m}^{3}\right)\end{array}$ & $\mathbf{A}_{\mathbf{s}}(\mathbf{m} / \mathbf{s})$ & $\mathbf{n}_{\mathbf{s}}$ \\
\hline Moutere Gravel & 20 & 662 & 0.471 \\
\hline Port Hill Gravel & 20 & 559 & 0.267 \\
\hline Stoke Fan Gravel & 20 & 430 & 0.260 \\
\hline Hope Gravel & 20 & 385 & 0.117 \\
\hline Tahunanui Sand (Silt/Sand/Gravel) & 18 & 254 & 0.224 \\
\hline Nelson Alluvium & 18 & 342 & 0.306 \\
\hline Dense Gravel [60] & 18 & 312 & 0.331 \\
\hline Dense Sand [60] & 18 & 255 & 0.261 \\
\hline Imperial Valley Soft Sands, Silts and Clays [58] & 17 & 192 & 0.273 \\
\hline Canterbury Gravel only sites gravels [16] & 19.6 & 547 & 0.15 \\
\hline Canterbury Interbedded sites gravels [16] & 19.6 & 369 & 0.26 \\
\hline Canterbury Interbedded sites soft soils [16] & 17.3 & 229 & 0.44 \\
\hline
\end{tabular}




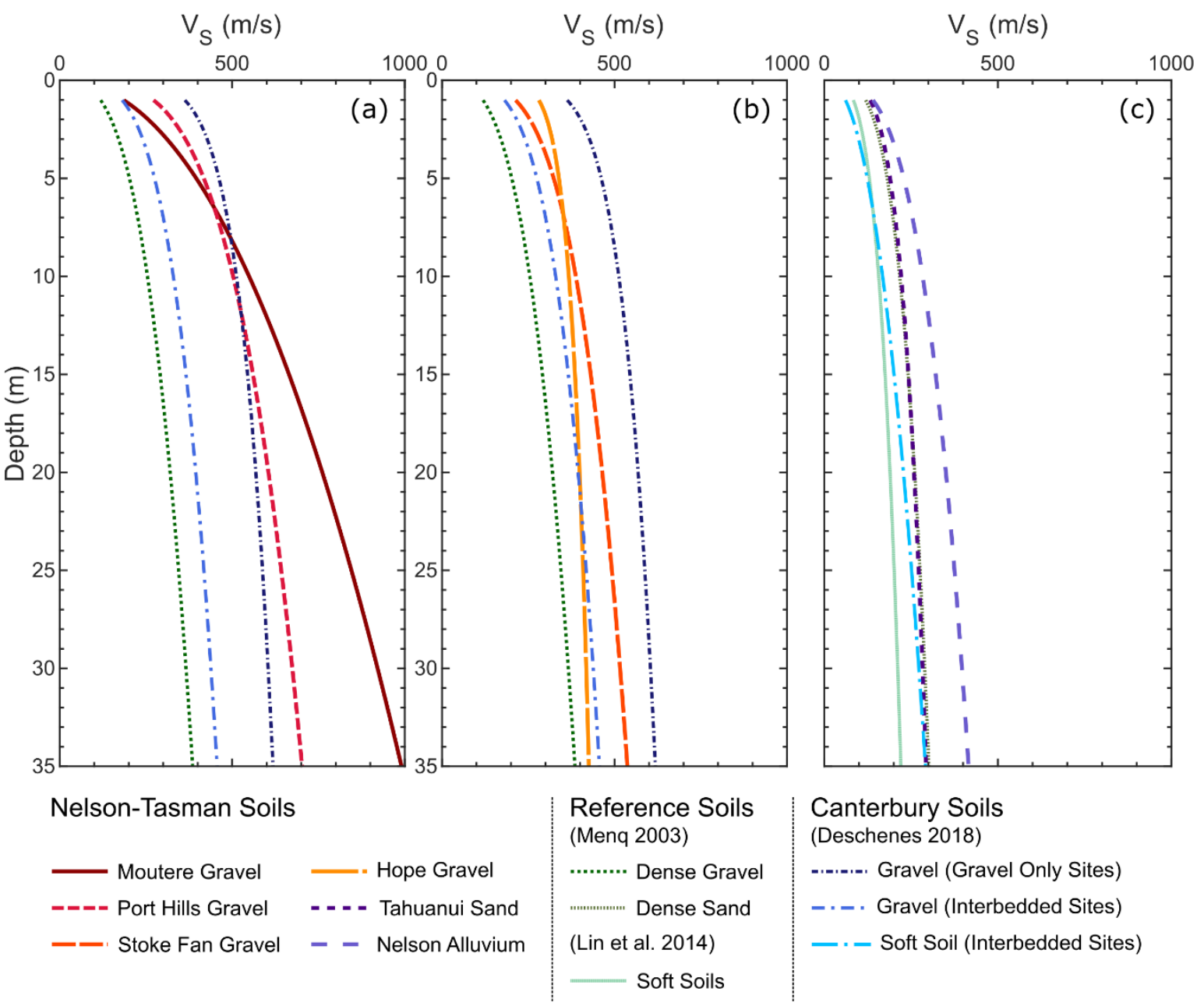

Figure 8: Depth-Vs models for (a) predominantly gravel formations (b) interbedded gravel formations and (c) fine grained and sand formations.

The Tahunanui Sand formation includes proportions of silt, sand and gravel at depth, so the equation coefficients are deemed to be reasonable for the types of soil expected within this unit. However as there were only three sites tested with Tahunanui Sand present, the data may potentially be biased due to the lack of data points to capture the true range of the formation. Given the age and depositional environment of the Tahunanui Sand formation, these sands are likely to be normally consolidated. The Tahunanui Sand $V_{s}$ relationship parameters and example curves nearly match the 'dense sand' materials from Menq [60].

Comparison with the models for the Canterbury deposits has clearly demonstrated the presence of the higher $\mathrm{V}_{\mathrm{S}}$ formations in the Nelson-Tasman deposits as a result of the different geologic processes that the region has experienced. This highlights the need for both geotechnical and geophysical information to appropriately characterise different geological units.

\section{Seismic Site Classification}

The basis of the dynamic site characterisation referenced in this research is formed around the New Zealand code for Structural Design Actions, part 5 Earthquake Actions (NZS1170.5) which can utilise the $V_{S}$ profile and fundamental site period to differentiate between site classes adopted for seismic design and assessment [61]. Site classification according to NZS1170.5 refers to the fundamental site period of a site to determine the site class used for seismic design. Site Class A and B related to sites where rock is at or near ground surface.
Site Class C and D are differentiated by the fundamental period of the soil profile above the bedrock (site period), with Site Class $\mathrm{C}$ locations have a site period less than 0.6 seconds. Site Class E relates to very deep and/or very soft soil sites.

Due to the complex geology in Nelson and deep deposits of uncemented gravel in Tasman, it is often difficult to determine the depth to seismic bedrock and therefore the NZS1170.5 Site Class of a given location. The results of the HVSR testing across the region were not conclusive as this testing method relies on a clear impedance contrast at depth that as discussed may not be present. In urban areas of Tasman, much of the deeper geology is comprised of gravel deposits, such as the Moutere Gravel which can be hundreds of metres deep. Nelson also has complex geology in the urban areas and where there is Port Hills Gravel, the weathered clay-bound gravel of this formation near-surface gradually transitions to conglomerate rock, usually within $30 \mathrm{~m}$ of the ground surface or less (Wopereis personal communication 2018). Even in areas thought to be underlain by rock at a relatively shallow depth (30 $\mathrm{m}$ or less), the impedance contrasts from the testing carried out was often found to be insufficiently clear to produce a notable peak in the HVSR data.

For some areas of Nelson-Tasman, it is possible to use the published geology to estimate the depth to bedrock which can then be used along with $\mathrm{V}_{\mathrm{S}}$ data collected in this study to infer the site class according to NZS1170.5 guidelines [61]. Locations that are underlain by Port Hills Gravels conglomerate and the areas above shallow rock to the south and east of Nelson are likely to be Site Class C, with a fundamental period less than 
0.6 seconds. Moving towards the centre and along the coast to the north of Nelson, classification is less certain, with thicker soils above the bedrock deposits in this area. In areas where the Moutere Gravels dominate the soil profile, Site Class D is likely appropriate when more than a few hundred metres away from the surrounding hills. The difficulty is that there is some uncertainty as to whether the NZS1170.5 framework accurately captures the potential dynamic site response for the NelsonTasman region. The lack of any significant impedance contrast for shallow profiles above engineering bedrock in the region reduces the potential amplification compared to a profile with a similar thickness but with lower Vs that is encountered in other regions. For this reason, site specific geotechnical investigations and specialist interpretation of site data can further refine the potential site amplification effects in this region.

\section{CONCLUSIONS}

This project is the first regional study of Nelson-Tasman utilising active and passive surface wave methods to assess the dynamic characteristics of the subsoil materials. Relationships for estimated $V_{S}$ with depth were derived for prominent regional formations by combining a range of geotechnical and geophysical investigation techniques.

The Nelson-Tasman area is thought to have undergone cycles of geological uplift which has produced much denser, overconsolidated units that are likely to have relatively high $\mathrm{V}_{\mathrm{s}}$. This highlights the need for soil characterisation of the NelsonTasman units both through geotechnical and geophysical testing methods, rather than relying on geological descriptions alone. For the younger deposits of Stoke Fan Gravel, Hope Gravel, Tahunanui Sand and Nelson Alluvium, the $V_{\text {s }}$ is similar to that expected for a 'Dense Gravel' deposit. While all of these deposits do contain proportions of gravel, they would not typically be labelled as a 'dense gravel', indicating that the $V_{S}$ is higher than expected when compared to literature.

$\mathrm{V}_{\mathrm{s}}$ along with site period are two fundamental parameters for seismic site classification, however it was found in NelsonTasman that HVSR based site period measurements were often inconclusive. Only small peaks in the HVSR curves based on ambient microtremor data was identified at more than 50 sites around Nelson-Tasman, likely caused by a lack of an impedance contrast between the overlying soil and seismic bedrock at depth. Further research is required into the depth to seismic bedrock and how this might influence the intensity of shaking in future earthquakes.

\section{ACKNOWLEDGEMENTS}

This project was supported by QuakeCoRE, a New Zealand Tertiary Education Commission-funded Centre and the Earthquake Commission. This is QuakeCoRE publication number 0626 . We would like to acknowledge the assistance of Nelson City Council and Tasman District Council and the civil engineering community across the region.

\section{REFERENCES}

1 Seed HB, Idriss IM and Dezfulian H (1967). "Relationships between Soil Conditions and Building Damage in the Caracas Earthquake of July, 29, 1967'. Earthquake Engineering Research Center, Report No. EERC 70-2, University of California, Berkeley, USA.

2 Duke CM, Johnsen KE, Larson LE and Engman DC (1972). "Effects of Site Classification and Distance on Instrumental Indices in the San Fernando Earthquake". UCLA Eng7247, University of California, Los Angeles, USA.
3 Romo MP, Jaime A and Resendix D (1988). "General soil conditions and clay properties in the valley of Mexico". Earthquake Spectra, 4: 731-752. https://doi.org/10.1193/1.1585499

4 Seed RB, Dickenson SE, Riemer MF, Bray JD, Sitar N, Mitchell JK, Idriss IM, Kayen RE, Kropp A, Harder LF and Power MS (1990). "Preliminary Report on the Principal Geotechnical Aspects of the October 17, 1989 Loma Prieta Earthquake". Report UCB/EERC-90/05, Earthquake Engineering Research Center, University of California, Berkeley.

5 Bradley BA and Cubrinovski M (2011). "Near-source strong ground motions observed in the 22 February 2011 Christchurch earthquake". Seismological Research Letters, 82(6): 853-865. https://doi.org/10.1785/gssrl.82.6.853

6 Bradley BA (2012). "Strong ground motion characteristics observed in the 4 September 2010 Darfield, New Zealand earthquake". Soil Dynamics and Earthquake Engineering, 42: 32-46. https://doi.org/10.1016/j.soildyn.2012.06.004

7 Holden C, Kaiser AE, Van Dissen R and Jury R (2013). "Sources, ground motion and structural response characteristics in Wellington of the 2013 Cook Strait earthquakes". Bulletin of the New Zealand Society for Earthquake Engineering, 46(4): 188-195. https://doi.org/10.5459/bnzsee.46.4.188-195

8 Bradley BA, Wotherspoon LM, Kaiser AE, Cox BR and Jeong S (2018). "Influence of Site Effects on Observed Ground Motions in the Wellington Region from the Mw 7.8 Kaikōura, New Zealand, Earthquake". Bulletin of the Seismological Society of America, 108(3B): 1722-1735. https://doi.org/10.1785/0120170286

9 Semmens S, Perrin ND and Dellow GD (2010). "It's Our Fault: Geological and Geotechnical Characterisation of the Wellington Central Business District". GNS Science Consultancy Report 2010/176, Lower Hutt.

10 Boon D, Perrin ND, Dellow GD, Van Dissen R and Lukovic B (2011). "NZS1170.5:2004 site subsoil classification of Lower Hutt". Proceedings of the Ninth Pacific Conference on Earthquake Engineering, 14-16 April, Auckland.

11 Kaiser A, van Houtte C, Perrin N, Wotherspoon LM and McVerry G (2017) "Site characterisation of GeoNet stations for the New Zealand strong motion database". Bulletin of the New Zealand Society for Earthquake Engineering, 50(1): 39-49. https://doi.org/10.5459/bnzsee.50.1.39-49

12 Wood CM, Cox BR, Wotherspoon LM and Green RA (2011). "Dynamic site characterization of Christchurch strong motion stations". Bulletin of the New Zealand Society for Earthquake Engineering, 44(4): 195-204. https://doi.org/10.5459/bnzsee.44.4.195-204

13 Wotherspoon LM, Orense RP, Bradley BA, Cox BR, Wood CM and Green RA (2014). "Geotechnical Characterisation of Christchurch Strong Motion Stations". Earthquake Commission Biennial Grant Report, Project No. 12/629, NZ.

14 Teague D, Cox BR, Bradley BA and Wotherspoon LM (2017). "Development of deep shear wave velocity profiles with estimates of uncertainty in the complex interbedded geology of Christchurch". Earthquake Spectra, 34(2): 639672. https://doi.org/10.1193/041117EQS069M

15 Wotherspoon LM, Bradley BA, Hills A, Thomson EM, Jeong S, Wood CM and Cox BR (2015). "Development of deep VS profiles and site periods for the Canterbury region" New Zealand Society for Earthquake Engineering Annual Technical Conference, 10-12 April, Rotorua, NZ. 
16 Deschenes MR, Wood CM, Wotherspoon LM, Bradley BA and Thomson E (2018). "Development of deep shear wave velocity profiles in the Canterbury plains, New Zealand". Earthquake Spectra, 34(3): 1065-1089. https://doi.org/10.1193/122717EQS267M

17 Lee R, Bradley BA, Ghisetti FG and Thomson EM (2017). "Development of a 3D velocity model of the Canterbury, New Zealand region for broadband ground motion simulation". Bulletin of the Seismological Society of America, 107(5): 2131-2150. https://doi.org/10.1785/0120160326

18 Cox BR and Vantassel J (2018). "Dynamic Characterization of Wellington, New Zealand". DesignSafe-CI Dataset. https://doi.org/10.17603/DS24M6J

19 Vantassel J, Cox BR, Wotherspoon LM and Stolte AS (2018). "Mapping depth to bedrock, shear stiffness, and fundamental site period at CentrePort, Wellington, using surface-wave methods: Implications for local seismic site amplification". Bulletin of the Seismological Society of America, 108(3B): 1709-1721. https://doi.org/10.1785/0120170287

20 Kaiser AE, Hill MP, Wotherspoon LM, Bourguignon S, Bruce ZR, Morgenstern R and Giallini S (2019). "Updated 3D Basin Model and NZS1170.5 Subsoil Class and Site Period Maps for the Wellington CBD". GNS Science Consultancy Report 2019/01. Lower Hutt, NZ.

21 Lee K and Wotherspoon LM (2019). "Dynamic characterisation of Auckland City reclamation zones". 13th Australia New Zealand Conference on Geomechanics, 1-3 April, Perth, Australia.

22 Pearse-Danker E and Wotherspoon LM (2016). "Site subsoil class determinations in Tauranga". New Zealand Society for Earthquake Engineering Annual Technical Conference, 1-3 April, Christchurch, NZ.

23 Jeong S and Wotherspoon LM (2019). "Development of a Waikato Basin T0 and depth model by the H/V spectral ratio method", 2019 Pacific Conference on Earthquake Engineering, 4-6 April, Auckland, NZ.

24 Perrin N, Heron D, Kaiser A and van Houtte C (2015). "Vs30 and NZS 1170.5 site class maps of New Zealand". New Zealand Society for Earthquake Engineering Annual Technical Conference, 10-12 April, Rotorua, NZ.

25 Foster KM, Bradley BA, McGann CR and Wotherspoon LM (2019). "A Vs30 map for New Zealand based on geologic and terrain proxy variables and field measurements". Earthquake Spectra, 35(4): 1865-1897. https://doi.org/10.1193/121118EQS281M

26 Laird MG and Bradshaw JD (2004). "The break-up of a long-term relationship: the Cretaceous separation of New Zealand from Gondwana". Gondwana Research, 7: 273286. https://doi.org/10.1016/S1342-937X(05)70325-7

27 Mortimer N, Campbell HJ, Tulloch AJ, King PR, Stagpoole VM, Wood RA, Rattenbury MS, Sutherland R, Adams CJ, Collot J and Seton M (2017). "Zealandia - Earth's hidden continent". GSA Today, 27: 27-35. https://doi.org/10.1130/GSATG321A.1

28 Ghisetti FC, Johnston MR and Wopereis P (2019). "Structural evolution of the active Waimea-Flaxmore Fault System in the Nelson-Richmond urban area, South Island, New Zealand". New Zealand Journal of Geology and Geophysics, 63(2): 168-189.

https://doi.org/10.1080/00288306.2019.1651346

29 Johnston M and Nicol A (2013). "Assessment of the Location and Paleoearthquake History of the WaimeaFlaxmore Fault System in the Nelson-Richmond Area with Recommendations to Mitigate the Hazard Arising from Fault Rupture of the Ground Surface". GNS Science Consultancy Report 2013/186, Lower Hutt, NZ.
30 Rattenbury MS, Cooper RA and Johnston MR (1998). "Geology of the Nelson Area". Lower Hutt: Graphic Press \& Packaging Ltd, NZ.

31 Johnston M (1979). "Geology of the Nelson Urban Area (1:25 000)", New Zealand Geological Survey Urban Series Map 1. Wellington: Department of Scientific and Industrial Research, NZ.

32 Westerson J (2007). "Fill Compaction Criteria for Port Hills Gravel Formation Soils, Nelson". Master Thesis, University of Canterbury, Christchurch, NZ.

33 Weir J (2014). "Stoke Deep Moutere Gravel Groundwater Management Guidelines". Aqualinc Research Ltd, Wellington, NZ.

34 McVerry GH, Van Dissen RJ and Abbot ER (2017). "Seismic Hazard Assessment for the Proposed Waimea Dam". GNS Science Consultancy Report 2017/150, Lower Hutt, NZ.

35 Fraser J (2005). "Paleoseismic Investigation of the Waimea-Flaxmore Fault System Nelson Region". Master Thesis, University of Canterbury, Christchurch, NZ.

36 Berryman KR, Cochran UA, Clark KJ, Biasi GP, Langridge RM and Villamor P (2012). "Major earthquakes occur regularly on an isolated plate boundary fault". Science, 336(6089): 1690-1693. https://doi.org/10.1126/science.1218959

37 Howarth JD, Barth NC, Fitzsimons SJ, Richards-Dinger K, Clark KJ, Biasi GP, Cochran UA, Langridge RM, Berryman K and Sutherland R (2021). "Spatiotemporal clustering of great earthquakes on a transform fault controlled by geometry". Nature Geoscience, 14(5): 314320. https://doi.org/10.1038/s41561-021-00721-4

38 Park CB, Miller RD and Xia J (1999). "Multichannel analysis of surface waves (MASW)". Geophysics, 64(3): 800-808. https://doi.org/10.1190/1.1444590

39 Foti S, Hollender F, Garofalo F, Albarello D, Asten M, Bard PY, Comina C, Cornou C, Cox B, Di Giulio G, Forbriger T, Hayashi K, Lunedei E, Martin A, Mercerat D, Ohrnberger M, Poggi V, Renalier F, Sicilia D and Socco V (2018). "Guidelines for the good practice of surface wave analysis: a product of the InterPACIFIC project". Bulletin of Earthquake Engineering, 16: 2367-2420. https://doi.org/10.1007/s10518-017-0206-7

40 Zywicki DJ (1999). "Advanced Signal Processing Methods Applied to Engineering Analysis of Seismic Surface Waves". PhD Dissertation, Georgia Institute of Technology, Atlanta, USA.

41 Asten MW and Henstridge JD (1984). "Array estimators and the use of microseisms for reconnaissance of sedimentary basins". Geophysics, 49(11): 1828-1837. https://doi.org/10.1190/1.1441596

42 Capon J (1969). "High resolution frequency-wavenumber spectrum analysis". Proceedings of IEEE, 57(8): 14081418. https://doi.org/10.1109/PROC.1969.7278

43 Wathelet M (2008). "An improved neighbourhood algorithm: Parameter conditions and dynamic scaling". Geophysical Research Letters, 35: L09301. https://doi.org/10.1029/2008GL033256

44 Thomson WT (1950). "Transmission of elastic waves through a stratified solid medium". Journal of Applied Physics, 21: 89-93. https://doi.org/10.1063/1.1699629

45 Haskell NA (1953). "The dispersion of surface waves on multilayered media”. Bulletin of the Seismological Society of America, 43: 17-34. https://doi.org/10.1785/BSSA0430010017 
46 Dunkin JW (1965). "Computation of modal solutions in layered, elastic media at high frequencies". Bulletin of the Seismological Society of America, 55: 335-358. https://doi.org/10.1785/BSSA0550020335

47 Knopoff L (1964). "A matrix method for elastic wave problems". Bulletin of the Seismological Society of America, 54: 431-438. https://doi.org/10.1785/BSSA0540010431

48 Wathelet M, Jongmans D and Ohrnberger M (2004). "Surface-wave inversion using a direct search algorithm and its application to ambient vibration measurements". Near Surface Geophysics, 2(4): 211-221. https://doi.org/10.3997/1873-0604.2004018

49 Cox BR and Teague DP (2016). "Layering ratios: A systematic approach to the inversion of surface wave data in the absence of a-priori information". Geophysical Journal International, 207: 422-438. https://doi.org/10.1093/gji/ggw282

50 Teague DP and Cox BR (2016) "Site response implications associated with using non-unique vs profiles from surface wave inversion in comparison with other commonly used methods of accounting for vs uncertainty". Soil Dynamics and Earthquake Engineering, 19: 87-103. https://doi.org/10.1016/j.soildyn.2016.07.028

51 Griffiths SC, Cox BR, Rathje EM and Teague DP (2016). "A surface wave dispersion approach for evaluating statistical models that account for shear wave velocity uncertainty". Journal of Geotechnical and Geoenvironmental Engineering, 142(11). https://doi.org/10.1061/(ASCE)GT.1943-5606.0001552

52 SESAME (2004). "Guidelines for the Implementation of the $H / V$ Spectral Ratio Technique on Ambient Vibrations: Measurements, Processing and Interpretation". Deliverable D23.12, European Commission-Research General Directorate, Brussels, Belgium.
53 Wotherspoon LM, Hayden C, Stolte AS, Bradley BA, Lee R, Jeong S and Kaiser AE (2020). "'Rapid' Geophysical Characterisation of New Zealand Sedimentary Basins using the Horizontal-to-Vertical Spectral Ratio Method". Earthquake Commission Biennial Grant Report, Project No. $18 / 761$, NZ.

54 ASTM (2019). "ASTM D7400 / D7400M-19 Standard Test Methods for Downhole Seismic Testing". ASTM International, West Conshohocken, USA. https://doi.org/10.1520/D7400_D7400M-19

55 Patel NS (1981). "Generation and Attenuation of Seismic Waves in Downhole Testing". Master Thesis, The University of Texas at Austin, Austin, TX, USA.

56 Kim DS, Bang ES and Kim WC (2004). "Evaluation of various downhole data reduction methods for obtaining reliable Vs profiles". Geotechnical Testing Journal, 27(6): 585-597. https://doi.org/10.1520/GTJ11811

57 Redpath BB (2007). "Downhole Measurements of Shearand Compression-Wave Velocities in Boreholes C4993, C4996, C4997, and C4998 at the Waste treatment Plant DOE Hanford Site". Redpath Geophysics, CA, USA. www.pnl.gov/main/publications/external/technical_reports /PNNL-16559.pdf

58 Lin YC, Joh SH and Stokoe KH (2014). "Analysis of the UTexas 1 surface wave dataset using the SASW methodology". Geo-Congress 2014, 23-26 February, Atlanta, Georgia, USA. https://doi.org/10.1061/9780784413272.081

59 Holtz RD, Kovacs WD and Sheahan TC (2011). An Introduction to Geotechnical Engineering. Second Edition, ISBN 978-0132496346, Pearson, 864 pages.

60 Menq F-Y (2003). "Dynamic Properties of Sandy and Gravelly Soils". PhD Dissertation, The University of Texas at Austin, Austin, TX, USA.

61 Standards New Zealand. (2004). "Structural Design Actions, Part 5: Earthquake Actions - New Zealand". Standards New Zealand, Wellington, NZ. 